\title{
Comparison of carbon footprint and net ecosystem carbon budget under organic material retention combined with reduced mineral fertilizer
}

\author{
Ying Liu ${ }^{1,2^{*}} \mathbb{0}$, Haiying Tang ${ }^{1,2}$, Pete Smith ${ }^{3}$, Chuan Zhong ${ }^{4}$ and Guoqin Huang ${ }^{2^{*}}$
}

\begin{abstract}
Background: Excessive application of chemical fertilizer has resulted in lower nitrogen uptake and utilization efficiency of crops, decreasing soil fertility, increasing greenhouse gas emissions, and worse environmental pollution. Organic material retention is regard as the key to solve these problems. The objective of this study is to conduct an assessment of carbon budget under Astragalus sinicus L. and rice straw retention combined with reduced mineral fertilizer based on the 2-year field experiment in a paddy field in the south of China. The experiment was randomized complete block design including four treatments with triplicates: control CK (winter follow, $120 \mathrm{~kg} \mathrm{ha}^{-1} \mathrm{~N}$ fertilizer for each rice season) and three treatments with Astragalus sinicus $L$. and rice straw retention named $R A$, $R B$, and $R C$ (reduced $\mathrm{N}$ fertilizer by $15 \%, 27.5 \%$, and $40 \%$ in each rice season).
\end{abstract}

Results: Treatments RA, RB, and RC increased greenhouse gas emissions by 9.30-101.25\%, among which $\mathrm{CH}_{4}$ accounted for more than 60\%; Carbon input of crops from treatments RA, RB, and RC increased by 2.25-12.10\% compared with control $\mathrm{CK}$ over the 2 years. Though treatments $\mathrm{RA}, \mathrm{RB}$, and $\mathrm{RC}$ enhanced $\mathrm{CO}_{2}$ emissions, treatment $\mathrm{RB}$ decreased carbon footprint and became carbon sink.

Conclusions: The results of this study reveal that treatment RB (Astragalus sinicus L. and rice straw retention with reduced $\mathrm{N}$ fertilizer by $27.5 \%$ ) is better in reducing chemical fertilizer amount, increasing crop yield and carbon input, which is more conductive to sustainable development of agriculture.

Keywords: Astragalus sinicus L., Rice straw, Reduced mineral fertilizer, Carbon footprint, Greenhouse gas emissions, Net ecosystem carbon budget

*Correspondence: 632084441@qq.com; hgqjxes@sina.com

${ }^{1}$ College of Agriculture and Biotechnology, Hunan University of Humanities, Science and Technology, Dixing Road, Louxing District, Loudi 417000, Hunan, China

${ }^{2}$ Research Center on Ecological Sciences, Jiangxi Agricultural University, No. 1101 Zhimin Avenue, Nanchang Economic and Technological Development Zone, Nanchang 330045, Jiangxi, China

Full list of author information is available at the end of the article

\section{Background}

Carbon $(\mathrm{C})$ footprint refers to the total carbon dioxide $\left(\mathrm{CO}_{2}\right)$ emissions generated directly or indirectly by an activity or product throughout its life cycle and expressed in $\mathrm{CO}_{2}$ equivalent $\left(\mathrm{CO}_{2}\right.$-eq) [1]. Greenhouse gas (GHG) emissions from agriculture accounts for $20-30 \%$ in the globe [2]. The $C$ footprint in agriculture can systematically evaluate the indirect $C$ emissions (diesel, electricity, fertilizer, pesticide and agricultural film) from agricultural inputs and the total amount of direct $\mathrm{C}$ emissions [3]. The $\mathrm{C}$ budget and balance includes $\mathrm{C}$ input (mostly

c) The Author(s) 2021. This article is licensed under a Creative Commons Attribution 4.0 International License, which permits use, sharing, adaptation, distribution and reproduction in any medium or format, as long as you give appropriate credit to the original author(s) and the source, provide a link to the Creative Commons licence, and indicate if changes were made. The images or other third party material in this article are included in the article's Creative Commons licence, unless indicated otherwise in a credit line to the material. If material is not included in the article's Creative Commons licence and your intended use is not permitted by statutory regulation or exceeds the permitted use, you will need to obtain permission directly from the copyright holder. To view a copy of this licence, visit http://creativeco mmons.org/licenses/by/4.0/. The Creative Commons Public Domain Dedication waiver (http://creativecommons.org/publicdomain/ zero/1.0/) applies to the data made available in this article, unless otherwise stated in a credit line to the data. 
coming from crop $\mathrm{C}$ sequestration) and $\mathrm{C}$ output (direct and indirect GHG emissions) in agriculture ecosystem.

Rice is one of the important crops in the world while paddy field is also an important agriculture GHG emissions source [4]. Rice planting area in China occupies approximately $19 \%$ in the world [5]. With the increase of population in the future, the demand for rice will inevitably increase, which will consume more energy, chemical fertilizers and pesticides, contributing directly and indirectly to GHG emissions from farmland. As an important greenhouse gas, $\mathrm{CO}_{2}$ contributes $60 \%$ to global warming, of which about 5-20\% comes from farmland soil [6]. According to the fifth report of IPCC, the atmospheric concentrations of $\mathrm{CO}_{2}$ had reached $391 \mathrm{ppm}$ by 2011, which were $40 \%$ higher than that before the Industrial Revolution [7]. Methane $\left(\mathrm{CH}_{4}\right)$ and nitrous oxide $\left(\mathrm{N}_{2} \mathrm{O}\right)$ emissions from paddy fields in China account for $17.9 \%$ and $80 \%$ of the total emissions and their concentrations are also increasing at the speed of 0.03 and $0.75 \mathrm{ppb}$ year $^{-1}$ in recent years [8-10].

Meanwhile, farmland ecosystem is also an important system for $\mathrm{C}$ sequestration and GHG mitigation. Increasing studies indicate that straw retention can sequestrate $\mathrm{C}$ and mitigate GHG emissions through directly inputting soil organic carbon (SOC) and increasing $\mathrm{C}$ storage $[11,12]$. China is abundant with crop straw resources, with an average annual production of 7.6-8.2 million tons [13], accounting for about $25 \%$ in the world [14] and the rice straw in the south of China accounts for about $50-60 \%$ [15].

Winter green manure and double-rice rotation is a traditional planting pattern in the south of China. Astragalus sinicus L. and rice straw contain a lot of nutrients and their reasonable application can not only replace part of chemical fertilizer, solve the adverse problems caused by excessive application of chemical fertilizer [16], but also avoid the waste of resources and environmental pollution resulted from straw burning [17] as well as increase SOC content $[11,12]$. However, increased $\mathrm{CH}_{4}$ emissions in paddy field after straw retention may offset GHG emissions mitigation effect of soil $\mathrm{C}$ sequestration $[18,19]$, which can not be ignored as an important GHG leakage. To clarify whether the reduced mineral fertilizer under Astragalus sinicus L. and rice straw retention can lower GHG emissions and enhance C sink, it is necessary to conduct an analysis to reveal whether there are tradeoffs between these two indicators by using $\mathrm{C}$ footprint and net ecosystem carbon budget (NECB).

At present, most studies mainly focus on the effect of different tillage systems and different rotation patterns on $C$ footprint [20-22]. Some researchers use the available data to calculate $C$ footprint or use remote sensing and numeric modeling to investigate the water-carbon interactions or simulate $\mathrm{C}$ sequestration [23-27]. However, little is known on comprehensive effects of reduced mineral fertilizer under organic material retention on $\mathrm{C}$ footprint and NECB. To provide theoretical basis for $\mathrm{C}$ sequestration and emissions mitigation of paddy field and sustainable development of agriculture, we conducted a 2-year field experiment to test the following hypotheses: (1) whether organic material retention combined with reduced mineral fertilizer can increase crop $C$ input? (2) whether C input can offset the increased GHG emissions? (3) Whether fertilizer and year had interactive effect on $\mathrm{C}$ footprint and NECB?

\section{Methods}

\section{Experiment site characteristics}

The field experiment was conducted in Yujiang County, Yingtan City from 2017 to 2019. This place belongs to subtropical monsoon humid climate with mean annual temperature and precipitation of $17.6{ }^{\circ} \mathrm{C}$ and $1741 \mathrm{~mm}$, respectively. Most of the soils are silt-deposited soils and a few are red loam soils. Before the experiment, the $\mathrm{pH}$, the content of organic matter, total nitrogen, total phosphorus, and total potassium in surface soil $(0-15 \mathrm{~cm})$ were $5.12,34.7 \mathrm{~g} \mathrm{~kg}^{-1}, 1.9 \mathrm{~g} \mathrm{~kg}^{-1}, 0.66 \mathrm{~g} \mathrm{~kg}^{-1}$, and $15.33 \mathrm{~g} \mathrm{~kg}^{-1}$.

\section{Experiment design and management}

The experiment adopts split plot design. The main zone includes two kinds of rice straw retention amount $(0$ and $6000 \mathrm{~kg} \mathrm{ha}^{-1}$ ). The secondary zone includes reduced chemical fertilizer at three different rates compared with control CK. There are four treatments with triplicates (Table 1): CK (winter fallow, without organic materials retention and $120 \mathrm{~kg} \mathrm{ha}^{-1} \mathrm{~N}$ fertilizer was applied for each rice season), and three treatments with Astragalus sinicus L. and rice straw retention combined with reduced mineral fertilizer named RA ( $-15 \% \mathrm{~N}$ fertilizer for each rice season), RB $(-27.5 \% \mathrm{~N}$ fertilizer for each rice season), and RC $(-40 \%$ $\mathrm{N}$ fertilizer for each rice season). Each plot area is $25 \mathrm{~m}^{2}$

Table 1 Field experimental design

\begin{tabular}{llcl}
\hline Treatments & $\begin{array}{l}\text { Chinese milk } \\
\text { vetch retention } \\
\text { amount }(\mathbf{k g} \\
\left.\mathbf{h a}^{-\mathbf{1}}\right)\end{array}$ & $\begin{array}{l}\text { Rice straw } \\
\text { retention } \\
\text { amount } \mathbf{( k g} \\
\left.\mathbf{h a}^{-1}\right)\end{array}$ & $\begin{array}{l}\text { N application } \\
\text { of each rice } \\
\text { season }(\mathbf{k g ~ h a}\end{array}$ \\
\hline CK & 0 & 0 & 120 \\
RA & Full & 6000 & $-15 \%$ \\
RB & Full & 6000 & $-27.5 \%$ \\
RC & Full & 6000 & $-40 \%$
\end{tabular}


$(5 \mathrm{~m} \times 5 \mathrm{~m})$, around which there are protection lines to prevent water and fertilizer cross-contamination.

The pure phosphorus and potassium was $20 \mathrm{~kg} \mathrm{ha}^{-1}$ and $60 \mathrm{~kg} \mathrm{ha}^{-1}$ respectively. $60 \%, 30 \%$, and $10 \% \mathrm{~N}$ fertilizer ( $\mathrm{N} 46 \%$ ) were used as basic, tiller and panicle fertilizer respectively. Phosphorus fertilizer $\left(\mathrm{P}_{2} \mathrm{O}_{5} 12 \%\right)$ was used as basic fertilizer and applied once. $70 \%$ and $30 \%$ potassium fertilizer $\left(\mathrm{K}_{2} \mathrm{O} 60 \%\right)$ was applied as tiller and panicle fertilizer. The $\mathrm{N}$ and $\mathrm{P}$ basic fertilizers were applied 1 day before rice transplanting, the tiller fertilizer was applied 5-7 days after rice transplanting and the panicle fertilizer was applied when the main stem was $1-2 \mathrm{~cm}$ long.

\section{Experiment materials}

The variety of Astragalus sinicus L. was Yujiang Daye. Seeds of $37.5 \mathrm{~kg} \mathrm{ha}^{-1}$ were sown on 3 October in 2017 and 7 October in 2018, and they were weighted, mixed, calculated the average value (retention amount of Astragalus sinicus L. was the same for each plot except control $\mathrm{CK})$, and plowed into the field at the blooming stage in the middle of April of next year. The early rice was "Yueru No. 6", which was transplanted on 26 April 2018 and 25 April 2019 and harvested on 12 July 2018 and 11 July 2019; the late rice was "Huarun No. 2", which was transplanted on 18 July 2018 and 15 July 2019 and harvested on 2 November 2018 and 16 November 2019. After the early rice harvest, the straw was cut into $3-5 \mathrm{~cm}$ sections with a guillotine, and then plowed into the field. After the late rice harvest, the straw was left and covered the field. The residue height of rice was $2-3 \mathrm{~cm}$.

\section{Measurement of items and methods \\ Collection and measurement of GHG}

GHG were collected by using static chamber with the size of $50 \mathrm{~cm} \times 50 \mathrm{~cm} \times 50 \mathrm{~cm}$. When the rice plant exceeded $50 \mathrm{~cm}$, the other chamber with the same size and two-way opening was added. There is one fixed sampling base with a groove of $5 \mathrm{~cm}$ depth filled with water when collecting the gas samples at per plot. Samples were collected from 8:00 to 11:00 every 7-8 days during rice growth period and every 15 days [28] in Astragalus sinicus L. growth season, respectively. A $50 \mathrm{ml}$ syringe was used to extract the gas at $0,10,20$ and $30 \mathrm{~min}$ and the syringe was pulsed back and forth 5-10 times to evenly mix the gas. After the gas was extracted and stored in vacuum bags, gas samples were quickly taken back and analyzed by using Agilent 7890A gas chromatography.

\section{Calculation of GHG}

The GHG flux is calculated according the equation:

$$
\mathrm{F}=\rho \times \mathrm{h} \times \mathrm{dc} / \mathrm{dt} \times 273 /(273+\mathrm{T})
$$

where $F$ is the gas emissions flux, $\rho$ is the gas density under standard conditions $\left(\mathrm{kg} \mathrm{m}^{-3}\right)$, $\mathrm{h}$ is the net height (m) of sampling chamber, $\mathrm{dc} / \mathrm{dt}$ is the change rate of gas concentration in the sampling chamber per unit time, $\mathrm{T}$ is the average temperature $\left({ }^{\circ} \mathrm{C}\right)$ in the sampling chamber during sampling process, and 273 is the constant of the gas equation.

The cumulative emissions of $\mathrm{CH}_{4}$ and $\mathrm{N}_{2} \mathrm{O}$ from paddy fields were calculated as follows:

$$
\operatorname{Tn}=\sum_{i=1}^{\mathrm{n}} F_{\mathrm{i}} * \mathrm{D}_{\mathrm{i}}
$$

where $\mathrm{Tn}$ is annual cumulative emissions, $\mathrm{F}_{\mathrm{i}}$ is the average daily emissions flux of $\mathrm{CH}_{4}$ and $\mathrm{N}_{2} \mathrm{O}$ between two sampling periods; $D_{i}$ is the number of days between two sampling intervals.

\section{C footprint calculation}

According to PAS 2050 [29], C footprint of agricultural production is calculated as the sum of all indirect and direct GHG emissions during one crop production in a certain cropping system $\left(\mathrm{kg} \mathrm{CO}_{2}\right.$-eq ha $\left.{ }^{-1}\right)$ based on life cycle assessment and expressed in $\mathrm{CO}_{2}$ equivalent $\left(\mathrm{CO}_{2}\right.$-eq). Therefore, in this study, $\mathrm{C}$ footprint of Astragalus sinicus L. and rice production includes indirect and direct GHG emissions, of which the former are from agricultural inputs (fertilizers, pesticides, machinery, electric irrigation) while the latter are from $\mathrm{CH}_{4}$ and $\mathrm{N}_{2} \mathrm{O}$ emission in paddy field. GHG emissions from agricultural inputs are estimated using the following formula:

$$
\mathrm{CE}_{\text {input }}=\sum\left(\mathrm{A}_{\mathrm{i}} \times \delta_{\mathrm{i}}\right) .
$$

In the formula, $\mathrm{CE}_{\text {input }}$ refers to the total GHG emissions $\left(\mathrm{kg} \mathrm{CO}_{2}\right.$-eq ha $\left.{ }^{-1}\right)$ from agricultural inputs, $i$ refers to a certain agricultural input, $\mathrm{Ai}$ is the intensity or quantity of the $i$ th individual agricultural input (pesticide/fertilizer, $\mathrm{kg} \mathrm{ha}^{-1}$; electricity, $\mathrm{kwh} \mathrm{ha}^{-1}$; Diesel, $\mathrm{L} \mathrm{ha}^{-1}$ ), and $\delta_{\mathrm{i}}$ is the coefficient factors of the $i$ th individual agricultural input. The GHG emissions factors from agricultural inputs are shown in Table 2.

$$
\mathrm{CF}=\left(\mathrm{CE}_{\text {input }}+\mathrm{EN}_{2} \mathrm{O}+\mathrm{ECH}_{4}\right) / \mathrm{Y}
$$

In the formula, $\mathrm{CF}$ refers to $\mathrm{C}$ footprint; $\mathrm{ECH}_{4}$ and $\mathrm{EN}_{2} \mathrm{O}$ refers to $\mathrm{CH}_{4}$ and $\mathrm{N}_{2} \mathrm{O}$ cumulative emissions, which are converted to $\mathrm{CO}_{2}$-eq from soils during Astragalus sinicus $\mathrm{L}$. and rice growth season; $\mathrm{Y}$ refers to the biomass of Astragalus sinicus L. and rice yield $\left(\mathrm{kg} \mathrm{ha}^{-1}\right)$.

\section{Total C input and NECB}

Total $C$ input based on $C$ sequestration in biomass was estimated using the following equation [30]. 
Table 2 Agricultural inputs (Ai), and related coefficient factors $\left(\delta_{i}\right)$ and application rate

\begin{tabular}{|c|c|c|c|c|c|c|}
\hline \multirow[t]{3}{*}{ Treatments } & \multirow{3}{*}{$\begin{array}{l}\text { GHG emission source } \\
\text { from agricultural inputs }\end{array}$} & \multirow{3}{*}{$\begin{array}{l}\text { Emission } \\
\text { coefficient }\end{array}$} & \multicolumn{4}{|c|}{ Agricultural inputs } \\
\hline & & & \multirow[t]{2}{*}{ Unit } & \multicolumn{3}{|c|}{ Application rate } \\
\hline & & & & $\begin{array}{l}\text { Chinese milk } \\
\text { vetch }\end{array}$ & Early rice & Late rice \\
\hline CK & N fertilizer & 6.38 & $\mathrm{~kg} \mathrm{ha}^{-1}$ & 0 & 120 & 120 \\
\hline RA & N fertilizer & 6.38 & $\mathrm{~kg} \mathrm{ha}^{-1}$ & 0 & 102 & 102 \\
\hline $\mathrm{RB}$ & $N$ fertilizer & 6.38 & $\mathrm{~kg} \mathrm{ha}^{-1}$ & 15 & 87 & 87 \\
\hline $\mathrm{RC}$ & N fertilizer & 6.38 & $\mathrm{~kg} \mathrm{ha}^{-1}$ & 30 & 72 & 72 \\
\hline Same for all the treatments & P fertilizer & 0.44 & $\mathrm{~kg} \mathrm{ha}^{-1}$ & 0 & 20 & 20 \\
\hline Same for all the treatments & K fertilizer & 0.61 & $\mathrm{~kg} \mathrm{ha}^{-1}$ & 0 & 60 & 60 \\
\hline Same for all the treatments & Diesel for machinery & 2.63 & $\mathrm{~kg} \mathrm{ha}^{-1}$ & 41 & 70 & 70 \\
\hline Same for all the treatments & Pesticide & 14.0 & $\mathrm{~kg} \mathrm{ha}^{-1}$ & 7 & 13 & 13 \\
\hline Same for all the treatments & Electricity for irrigation & 1.12 & $\mathrm{Kg} \mathrm{ha}^{-1}$ & 0 & 468 & 468 \\
\hline
\end{tabular}

The data were obtained from the average value of agricultural input in this study. $\mathrm{N}$ represents nitrogen fertilizer; $\mathrm{P}$ represents phosphate fertilizer; $\mathrm{K}$ represents potash fertilizer; GHG represents greenhouse gas

$$
\begin{aligned}
\mathrm{E}_{\text {input }}= & \mathrm{B}_{\text {total }}\left(\mathrm{B}_{\text {grain }}+\mathrm{B}_{\text {straw }}+\mathrm{B}_{\text {root }}\right. \\
& \left.+\mathrm{B}_{\text {litter }}+\mathrm{B}_{\text {rhizodeposites }}\right) \times \mathrm{f}_{\mathrm{c}} \times(44 / 12)
\end{aligned}
$$

Crop yield and straw were weighed on site; root biomass, litter, and rhizodeposits are calculated according to Salam et al. [31] and Huang et al. [32]; fc is the C percentage in grain ( $40 \%$ for rice) [33].

\section{Results and discussion GHG emissions}

The GHG emissions from all the treatments include indirect emissions from agricultural inputs (Table 2) and direct $\mathrm{CH}_{4}$ and $\mathrm{N}_{2} \mathrm{O}$ emissions (Table 3), among which the former accounts for more than $17 \%$ and the latter occupies more than $60 \%$. The GHG emissions from all

$$
\begin{aligned}
\mathrm{NECB}= & \mathrm{E}_{\text {input }}-\mathrm{E}_{\text {output }}\left(\mathrm{CO}_{2} \text { equivalent of } \mathrm{CH}_{4} \text { and } \mathrm{N}_{2} \mathrm{O} \text { cumulative emissions plus } \mathrm{CO}_{2}\right. \\
& \text { emissions from plant respiration and soil microbial respiration). }
\end{aligned}
$$

\section{Data analysis}

A statistical analysis was performed using Microsoft Excel 2010 and SPSS 17.0. Origin 9.0 was used to create a diagram. A mixed linear model was used to analyze the effects of fertilizer and year on mean GHG, $\mathrm{CO}_{2}$, $\mathrm{C}$ input, $\mathrm{C}$ footprint, crop biomass, and NECB during the crop growing season. Mean values for each variable were compared by a one-way ANOVA, followed by a Duncan's post hoc test $(P<0.05)$. the treatments ranged from 9731 to $19,584 \mathrm{~kg} \mathrm{CO}_{2}$-eq $\mathrm{ha}^{-1}$ and treatments RA, RB and RC with organic materials retention combined with reduced mineral fertilizer increased by $9.30-101.25 \%$ compared with that of control CK over the 2 years. The difference of GHG emissions between treatments RA, RC and control CK was significant $(P<0.05)$, while the difference between treatment $\mathrm{RB}$ and control CK was insignificant (Table 3), which may be caused by the different turnover depth and decompo-

\begin{tabular}{|c|c|c|c|c|c|c|c|c|c|c|c|}
\hline \multirow[t]{2}{*}{$\mathbf{T}$} & \multicolumn{6}{|c|}{ Indirect emission } & \multicolumn{2}{|c|}{ Direct emission } & \multirow{2}{*}{$\begin{array}{l}\text { Average GHG } \\
\text { emissions }\end{array}$} & \multirow[t]{2}{*}{ Yield ( kg ha-1) } & \multirow{2}{*}{$\begin{array}{l}\text { Carbon footprint ( } \mathrm{kg} \\
\mathrm{CO}_{2} \text {-eq } \mathrm{kg}^{-1} \text { grain) }\end{array}$} \\
\hline & $\mathbf{N}$ & $\mathbf{P}$ & K & Diesel & Electricity & Pesticides & $\mathrm{CH}_{4}$ & $\mathrm{~N}_{2} \mathrm{O}$ & & & \\
\hline CK & 1531 & 18 & 73 & 476 & 1048 & 462 & $5863 c$ & 260 & $9731 \mathrm{c}$ & $15209 b$ & $0.63 c$ \\
\hline RA & 1301 & 18 & 73 & 476 & 1048 & 462 & $16037 a$ & 169 & $19584 a$ & 19479a & $1.01 \mathrm{a}$ \\
\hline $\mathrm{RB}$ & 1206 & 18 & 73 & 476 & 1048 & 462 & $7164 c$ & 189 & $10636 c$ & 20530a & $0.52 c$ \\
\hline $\mathrm{RC}$ & 1110 & 18 & 73 & 476 & 1048 & 462 & $13577 b$ & 261 & $17025 b$ & $20124 a$ & $0.85 b$ \\
\hline
\end{tabular}
sition rate of Astragalus sinicus L. and rice straw in each plot. The study result of Zhu et al. [34] indicated that

Table 3 Average annual GHG emissions and C footprint during crop growth seasons over the two years ( $\mathrm{kg} \mathrm{CO}_{2}-\mathrm{eq} \mathrm{ha}^{-1}$ )

T represents treatment; GHG represents greenhouse gas; C represents carbon; yield represents Chinese milk vetch straw and rice biomass. The different lowercase letters indicate significant differences among treatments at $P<0.05$ 
different depth of straw retention $(0-10 \mathrm{~cm}, 10-20 \mathrm{~cm}$, 20-30 cm, 30-40 cm) had different effects on GHG emissions. The reason may be that the different depth of straw retention made the straw lie in different soil layers with different natural conditions and microbial diversity, which affected straw decomposition rate $[35,36]$ and SOC content [37], thus affecting GHG emissions. From Table 5 we can see that straw retention had significant effect on GHG, C input, and crop biomass. Year had significant impact on $\mathrm{CO}_{2}$ and NECB. Moreover, fertilizer and year had significant effect or interactive effect on GHG emissions, $\mathrm{CO}_{2}$, C footprint, and NECB.

\section{C footprint components of all the treatments}

The $\mathrm{C}$ emissions per unit area of all the treatments was 9731 to $19,584 \mathrm{~kg} \mathrm{CO}_{2}$-eq ha ${ }^{-1}$ and the $\mathrm{C}$ footprint per unit production was $0.52-1.01 \mathrm{~kg} \mathrm{CO}_{2}$-eq $\mathrm{kg}^{-1}$. The $\mathrm{C}$ footprint of all the treatments is mainly from $\mathrm{C}$ output of soil $\mathrm{CH}_{4}, \mathrm{~N}$ fertilizer and electricity consumption for irrigation (Table 2), accounting for 60.25-81.88\%, 6.64-15.73\% and 5.35-10.77\%, respectively (Fig. 1). Compared with $\mathrm{C}$ footprint of control CK, treatments RA and RC increased by $60.32 \%$ and $34.92 \%$, while treatment RB decreased by $17.46 \%$, which may attributed to the less $\mathrm{N}$ fertilizer application amount, lower $\mathrm{C}$ output of $\mathrm{CH}_{4}$ and $\mathrm{N}_{2} \mathrm{O}$ as well as higher yield of treatments $\mathrm{RB}$ (Table 3 ). Our result was consistent with previous studies which reported soil $\mathrm{CH}_{4}$ was dominate source of $\mathrm{C}$ footprint in paddy field $[38,39]$. Compared with control $\mathrm{CK}$, treatments $\mathrm{RA}, \mathrm{RB}$ and $\mathrm{RC}$ enhanced $\mathrm{CH}_{4}$ emissions, mainly resulting from the following aspects: (1) The continuous flooded irrigation provided a favorable anaerobic environment for the growth and reproduction of methanogens and methanotrophs (Fig. 2) [40-42]; (2) Mulching and retention of rice straw and Astragalus sinicus L. could maintain soil moisture, provide organic matter for soil and reduce soil redox potential, thus leading to $\mathrm{CH}_{4}$ emissions increase [43, 44]; (3) Organic materials retention supplied methanogenic bacteria with adequate substrates $[11,45,46]$, while the decomposition of straw consumed oxygen, enhanced soil anaerobic environment and inhibited the activity of methane oxidizing bacteria, thus promoting $\mathrm{CH}_{4}$ emissions [47]; (4) The application of mineral fertilizer and the decomposition of organic materials accelerated the rice and its root growth, thus making the secretion and abscission of rice root increase and providing a substrate for related microorganisms, resulting in the rapid increase of $\mathrm{CH}_{4}$ emissions [48].

Fertilizer and study year had significant interactive effect on $\mathrm{C}$ footprint (Table 5). Fertilizer (mineral fertilizer combined with organic materials) had different effect on GHG emissions when the rainfall and temperature were different over the 2 years, therefore, there

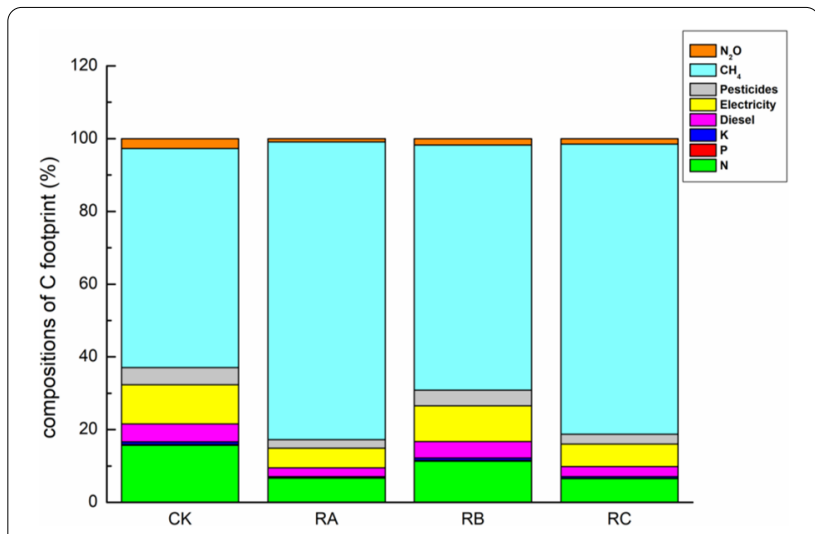

Fig. 1 Average annual compositions of C footprint during crop growth season over the 2 years
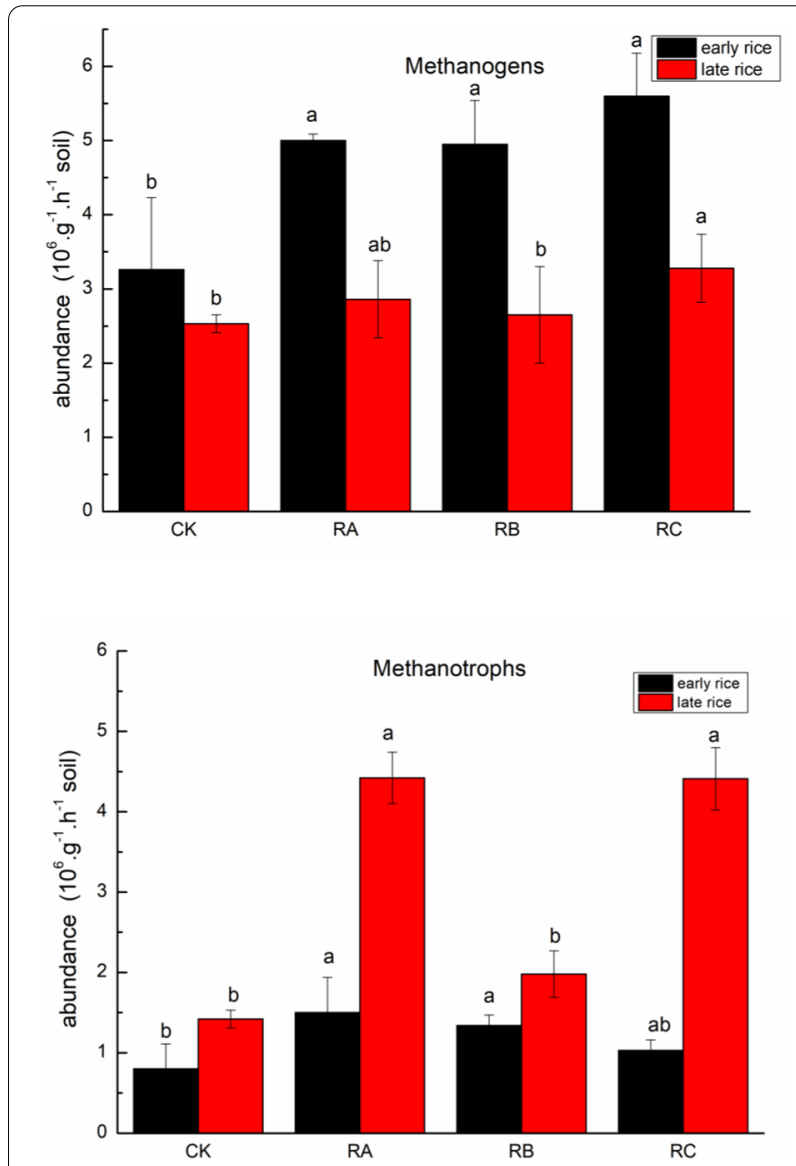

Fig. 2 Abundances of methanogens and methanotrophs during the 2018 rice season in response to incorporation of Chinese milk vetch and rice straw combined with reduced chemical fertilizer. Different lowercase letters in the same column indicate significant differences among the treatments at $P \leq 0.05$ 
exists an interactive effect between fertilizer and year. Different temperature and rainfall can affect the evaporation and loss rate of $\mathrm{N}$ fertilizer, thereby affecting $\mathrm{N}_{2} \mathrm{O}$ emissions because there was a linear relationship between $\mathrm{N}_{2} \mathrm{O}$ emissions and $\mathrm{N}$ fertilizer $[49,50]$. Meanwhile temperature, rainfall and crop straw retention also affect soil moisture and aeration condition, thus affecting GHG emissions. $\mathrm{CH}_{4}$ is produced in an anaerobic environment [51]. Nitrification is sufficient when the soil contains sufficient oxygen, while denitrification mainly occurs in poor oxygen environments in soils [52, 53]. Moreover, rainfall can improve the temperature of soil water, enhance microbial activity, increase organic matter or nitrogen mineralization rate, and promote the rapid release of large amounts of $\mathrm{C}$ and $\mathrm{N}$ in soil in a short period, thus promoting GHG emissions [54-56].

\section{NECB}

The NECB can be used to assess the short-term net $C$ budget balance via $\mathrm{C}$ input and output in an agro-ecosystem [57]. For control CK and the treatments with retention of Astragalus sinicus L. and rice straw combined with different amount of reduced mineral fertilizer, $\mathrm{C}$ input of crops varied from $31.98 \mathrm{Mg} \mathrm{CO}_{2}$-eq ha ${ }^{-1}$ to $35.85 \mathrm{Mg}$ $\mathrm{CO}_{2}$-eq ha ${ }^{-1}$ and $\mathrm{C}$ output ranged from $26.59 \mathrm{Mg}$ $\mathrm{CO}_{2}$-eq ha ${ }^{-1}$ to $40.79 \mathrm{Mg} \mathrm{CO}_{2}$-eq $\mathrm{ha}^{-1}$. Control CK and treatment $\mathrm{RB}$ became $\mathrm{C}$ sink compared with treatments $\mathrm{RA}$ and RC because control CK was winter fallow and its $C$ output was the least and treatments RB had the most crop biomass and $C$ input (Table 4). Straw retention had significant effect on crop biomass and $C$ input. The effect of study year as well as fertilizer * year on NECB was significant (Table 5).

$\mathrm{CO}_{2}$ emissions contributed to the largest proportion of $\mathrm{C}$ output. $\mathrm{CO}_{2}$ emissions was significantly affected by straw retention (Table 5). $\mathrm{CO}_{2}$ emissions from treatments $\mathrm{RA}, \mathrm{RB}$, and $\mathrm{RC}$ were higher than that of control CK (Table 4), which might result from the accumulation of soil total organic carbon, microbial biomass carbon, and dissolved organic carbon caused by Astragalus sinicus L. and straw retention. Moreover, the application of mineral fertilizer and the decomposition of straw also promoted the growth and reproduction of soil microorganisms, thus enhancing soil respiration and promoting soil $\mathrm{CO}_{2}$

Table 4 Assessment of $\mathrm{C}$ budget and balance in different treatments $\left(\mathrm{Mg} \mathrm{CO}_{2} \mathrm{ha}^{-1}\right)$

\begin{tabular}{|c|c|c|c|c|c|c|c|c|}
\hline \multirow[t]{2}{*}{ Items } & \multicolumn{2}{|l|}{ CK } & \multicolumn{2}{|l|}{ RA } & \multicolumn{2}{|l|}{ RB } & \multicolumn{2}{|l|}{$\mathrm{RC}$} \\
\hline & C input & Coutput & C input & Coutput & C input & C output & C input & C output \\
\hline$C$ input of Chinese milk vetch and rice & 31.98 & & 35.37 & & 35.85 & & 32.70 & \\
\hline GHG (direct and indirect) & & 9.73 & & 19.58 & & 10.64 & & 17.03 \\
\hline $\mathrm{CO}_{2}$ cumulative emissions & & 16.86 & & 21.21 & & 21.64 & & 19.78 \\
\hline Total & 31.98 & 26.59 & 35.37 & 40.79 & 35.85 & 32.29 & 32.70 & 36.80 \\
\hline NECB & 5.39 & & -5.42 & & 3.56 & & -4.1 & \\
\hline
\end{tabular}

GHG represents greenhouse gas; $\mathrm{CO}_{2}$ represents carbon dioxide; $\mathrm{C}$ represents carbon; $\mathrm{NECB}$ represents net ecosystem carbon budget

Table 5 Interactions of straw retention, fertilizer and study year on mean $\mathrm{GHG}, \mathrm{CO}_{2}, \mathrm{C}$ input, $\mathrm{C}$ footprint, crop biomass and NECB during the crop growing season

\begin{tabular}{|c|c|c|c|c|c|c|}
\hline & GHG & $\mathrm{CO}_{2}$ & C input & C footprint & Crop biomass & NECB \\
\hline \multicolumn{7}{|l|}{ Straw retention ${ }^{a}$} \\
\hline$-S R$ & 9731.44 & $16,860.67$ & $31,981.66$ & 0.65 & $15,208.83$ & 5.39 \\
\hline$+S R$ & $15,748.89^{* *}$ & $20,879.21$ & $34,641.17^{*}$ & 0.79 & $20,044.44^{* * *}$ & -1.99 \\
\hline \multicolumn{7}{|l|}{ Year $^{b}$} \\
\hline 2018 & $14,235.30$ & $26,169.29$ & $32,901.97$ & 0.78 & $18,278.67$ & -7.50 \\
\hline 2019 & $14,253.75$ & $13,579.86 * * *$ & $35,050.62$ & 0.73 & $19,392.42$ & $7.22^{* * *}$ \\
\hline \multicolumn{7}{|l|}{ F-values } \\
\hline Fertilizer * year & $51.458 * * *$ & $49.338^{* * *}$ & 0.924 & $6.271^{* *}$ & 1.000 & $6.689^{* *}$ \\
\hline
\end{tabular}

F-values are provided for interactions

GHG represents greenhouse gas; $\mathrm{CO}_{2}$ represents carbon dioxide; $\mathrm{C}$ represents carbon; NECB represents net ecosystem carbon budget; - SR represents no straw (Astragalus sinicus L. and rice) retention; $+\mathrm{SR}$ represents straw (Astragalus sinicus $\mathrm{L}$. and rice) retention

There were significant interactions (fertilizer ${ }^{*}$ year) for the six variables. ${ }^{*}(0.01<P \leq 0.05)$, ${ }^{* *}(0.001<P \leq 0.01)$, or ${ }^{* * *}(P \leq 0.001)$ are used to represent significant effects among the treatments

$a, b$ Values were averaged across different treatments, crop, and study years 
emissions [58-62]. With the growth of Astragalus sinicus $\mathrm{L}$. and rice plants, crop root secretion and abscission increased, which strengthened the microbial activity and rice respiration, thus increasing $\mathrm{CO}_{2}$ emissions [63, 64] . In addition, straw $\mathrm{C}$ decomposition also stimulated the mineralization of SOC to produce $\mathrm{CO}_{2}[65]$.

\section{Conclusion}

The GHG emissions of treatments RA, RB, and RC with organic material retention combined with reduced mineral fertilizer at the rate of $15 \%, 27.5 \%$, and $40 \%$ respectively increased by $9.30-101.25 \%$ over the two years compared with that of control CK. The increase resulted from increased soil $\mathrm{CH}_{4}$ emissions, which occupied more than $60 \%$. Meanwhile treatments RA, RB, and RC increased the yield (including Astragalus sinicus L., and rice biomass) by $28.08-34.99 \%$ compared with that of control CK. Treatment RB decreased C footprint which mainly attributed to reduced $\mathrm{N}$ fertilizer and higher bimass compare with control CK. Treatment RB (Astragalus sinicus $\mathrm{L}$. and rice straw retention with reduced $\mathrm{N}$ fertilizer by $27.5 \%$ ) became $C$ sink because increased $C$ input outweighed the increased $C$ output. These results suggest that treatment $\mathrm{RB}$ is better in reducing chemical fertilizer amount, increasing crop yield and $\mathrm{C}$ input, which is more conductive to sustainable development of agriculture.

\section{Supplementary Information}

The online version contains supplementary material available at https://doi. org/10.1186/s13021-021-00170-x.

Additional file 1: Figure S1. Experiment site.

\section{Abbreviations}

C: Carbon; N: Nitrogen; $\mathrm{CO}_{2}$ : Carbon dioxide; $\mathrm{GHG}$ : Greenhouse gas; $\mathrm{CH}_{4}$ : Methane; $\mathrm{N}_{2} \mathrm{O}$ : Nitrous oxide; SOC: Soil organic carbon; NECB: Net ecosystem carbon budget.

\section{Acknowledgements}

We would like to thank Yang Wenting, Yang Binjuan and Zhou Quan for their help in our research.

\section{Authors' contributions \\ LY conducted the field experiment and wrote the manuscript, THY and ZC analyzed the data, PS reviewed and edited the manuscript and HGQ applied for financial support for the project. All authors read and approved the final manuscript.}

\section{Funding}

This research was financially supported by the National Natural Science Foundation of China, Grant number: 41661070, the National Key R\&D Program, Grant numbers: 2016YFD0300208, and Jiangxi Provincial 2019 Postgraduate Innovation Fund Project (YC-2019-B060).

\section{Data sharing and data accessibility}

The data that supports the findings of this study are available in Additional file 1.
Ethics approval and consent to participate Not applicable.

\section{Consent for publication}

Not applicable.

\section{Competing interests}

The authors declare that they have no competing interests.

\section{Author details}

${ }^{1}$ College of Agriculture and Biotechnology, Hunan University of Humanities, Science and Technology, Dixing Road, Louxing District, Loudi 417000, Hunan, China. ${ }^{2}$ Research Center on Ecological Sciences, Jiangxi Agricultural University, No. 1101 Zhimin Avenue, Nanchang Economic and Technological Development Zone, Nanchang 330045, Jiangxi, China. ${ }^{3}$ Institute of Biological and Environmental Sciences, School of Biological Sciences, University of Aberdeen, 23 St Machar Drive, Room G45, Aberdeen AB24 3UU, Scotland, UK. ${ }^{4}$ College of Agriculture, Nanjing Agricultural University, Nanjing 210095, China.

Received: 19 August 2020 Accepted: 20 February 2021

Published online: 01 March 2021

\section{References}

1. World Resources Institute. Product accounting and reporting standard. Draft for stakeholder review. New standards for tracking GHG emissions from policies and goals. https://www.wri.org/blog/2012/12/relea sed-review-new-standards-tracking-ghg-emissions-policies-andgoals. Accessed 21 Oct 2010.

2. Vermeulen SJ, Campbell BM, Ingram JSI. Climate change and food systems. Annu Rev Env Resour. 2012;37:195-222.

3. Hillier J, Hawes C, Squire G, Hilton A, Wale S, Smith P. The carbon footprints of food crop production. Int J Agric Sustain. 2009;7(2):107-18.

4. Sun H, Zhou S, Fu Z, Chen G, Zou G, Song X. A two-year field measurement of methane and nitrous oxide fluxes from rice paddies under contrasting climate conditions. Sci Rep. 2016;6:1-11.

5. Cheng C, Zeng Y, Yang X, Huang S, Shang Q. Effect of different tillage methods on net global warming potential and greenhouse gas intensity in double rice-cropping systems. J Environ Sci-China. 2015;35(6):1887-95.

6. Zhang YM, Hu CS, Zhang JB, Dong WX, Wang YY, Song LN. Research advances on source/sink intensions and greenhouse effects of $\mathrm{Co}, \mathrm{CH}$ and in agricultural soils. Chin J Eco-Agric. 2011;19(4):966-75.

7. IPCC. Climate Change 2013: the physical science basis. Contribution of working group I to the fifth assessment report of the intergovernmental panel on climate change. Cambridge: Cambridge University Press, 2013.

8. Ghosh S, Majumdar D, Jain MC. Methane and nitrous oxide emissions from an irrigated rice of North India. Chemosphere. 2003;51(3):181-95.

9. WMO. The state of greenhouse gases in the atmosphere based on global observation through 2012. WMO Greenhouse Gas Bulletin. 2013;9:1-4.

10. Stocker TF, Qin D, Plattner GK, Tignor MMB, Allen SK, Boschung J, et al. Climate change 2013: the physical science basis. Contribution of working group I to the fifth assessment report of IPCC the Intergovernmental Panel on Climate Change. 2014;18(2):95-123. http://www.ipccch/publi cations_and_data/publications_ipcc_fourth_assessment_report_wg1_ report_the_physical_science_basishtm.

11. Liu C, Lu M, Cui J, Li B, Fang CM. Effects of straw carbon input on carbon dynamics in agricultural soils: a meta-analysis. Glob Change Biol. 2014;20(5):1366-81.

12. Wang W, Lai DYF, Wang C, Pan T, Zeng C. Effects of rice straw incorporation on active soil organic carbon pools in a subtropical paddy field. Soil Tillage Res. 2015;152:8-16.

13. Pan GX, Li LQ, Liu XY, Cheng K, Bian RJ, Ji CY, et al. Industrialization of biochar from biomass pyrolysis: a new option for straw burning ban and green agriculture of China. Sci Technol Rev. 2015;33(13):92-101.

14. Jiang CQ, Zheng QS, Zu CL. Research progress on effects of straw retention on soil potassium and its substitute for potassium fertilizer. Chin J Ecol. 2015;34(4):1158-65.

15. Zhu QH, Huang DY, Liu SL, Zhang WJ, Su YR, Wu JS. Status and prospects of crop straw comprehensive utilization in hilly red soil region. Chin J Ecol. 2005;24(12):1482-6. 
16. Zhou X, Liao Y, Yanhong LU, Xie J, Yang Z, Nie J, et al. Responses of contents of soil organic carbon fractions to chinese milk vetch-rice straw synergistic dispatching under the condition of reducing fertilizer application. J Soil Water Conserv. 2017;31(3):282-90.

17. Wang $L$, Li XM, XU Y. The economic losses caused by crop residues burnt in open field in China. J Arid Land Resour Env. 2008;22(2):170-5.

18. Lu F, Wang $X K$, Han B, Ouyang $Z Y$, Zheng $H$. Straw return to rice paddy: soil carbon sequestration and increased methane emission. Chin J Appl Ecol. 2010;21(1):99-108.

19. Naser HM, Nagata O, Tamura S, Hatano R. Methane emissions from five paddy fields with different amounts of rice straw application in central Hokkaido. Jpn Soil Sci Plant Nutr. 2010;53(1):95-101.

20. Zhang XQ, Pu C, Zhao X, Xue JF, Zhang R, Nie ZJ, et al. Tillage effects on carbon footprint and ecosystem services of climate regulation in a winter wheat-summer maize cropping system of the North China Plain. Ecol Indic. 2016;67:821-9.

21. Wang FJ, Zhang MY, Zhang HL, Chen F. Evaluation of tillage treatments on soil carbon sequestration in North China Plain. J China Agric Univ. 2012;17(4):40-5.

22. Jiang $Z H$, Yang $X$, Liu YZ, Lin JD, WuYang $X Y$, Yang JP. Comparison of carbon footprint between spring maize-late rice and early rice-late rice cropping system. Acta Ecol Sin. 2019;39(21):8091-9.

23. Xu X, Zhang B, Liu Y, Xue Y, Di B. Carbon footprints of rice production in five typical rice districts in China. Acta Ecol Sin. 2013;22(3):227-32.

24. Yan M, Cheng K, Luo T, Yan Y, Pan G, Rees RM. Carbon footprint of grain crop production in China-based on farm survey data. J Clean Prod. 2015:104:130-8

25. Sun PC, Wu YP, Xiao JF, Hui JY, Liu SG. Remote sensing and modeling fusion for investigating the ecosystem water-carbon coupling processes. Sci Total Environ. 2019;697:134064.

26. Zhao FB, Wu YP, Yao YY, Sun $K$, Zhang XS, Leigh W, et al. Predicting the climate change impacts on water-carbon coupling cycles for a loess hillygully watershed. J Hydrol. 2020;581:124388.

27. Qiu LJ, Wu YP, Hao MD, Shen J, Lei XH, Laio WH, Li YK. Simulation of the irrigation requirements for improving carbon sequestration in a rainfed cropping system under long-term fertilization on the Loess Plateau of China. Agric Ecosyst Environ. 2018;265:198-208.

28. Zhong C, Yang BJ, Zhang P, Li P, Huang GQ. Effect of paddy-upland rotation with different winter corps on rice yield and $\mathrm{CH}_{4}$ and $\mathrm{N}_{2} \mathrm{O}$ EMISSIONS IN PADDY FIELDS. Acta Agric Nucl Sin. 2019;33(2):0379-88.

29. BSI and Carbon Trust. Specification for the assessment of the life cycle greenhouse gas emissions of goods and services. Publicly Available Specification-PAS 2050: 2011. London, UK. p. 36.

30. Jiang ZH, Lin JD, Liu YZ, Mo CY, Yang JP. Double paddy rice conversion to maize paddy rice reduces carbon footprint and enhances net carbon sink. J Clean Prod. 2020;258:1-9.

31. Salam MU, Jones JW, Jones JGW. Phasic development of rice seedlings. Agron J. 1997;89:653-8.

32. Huang J, Chen Y, Sui P, Gao W. Estimation of net greenhouse gas balance using crop- and soil-based approaches: Two case studies. Sci Total Environ. 2013:456-457:299-306.

33. Dubey A, Lal R. Carbon footprint and sustainability of agricultural production systems in Punjab, India, and Ohio, USA. J Crop Improve. 2009;23(4):332-50.

34. Zhu XM, An J, Ma L, Chen SL, Li JQ, Zou H, et al. Effects of different straw returning depths on soil greenhouse gas emission and maize yield. Sci Agric Sin. 2020;53(5):977-89.

35. Coppens F, Garnier P, Gryze SD, Merckx R, Recous S. Soil moisture, carbon and nitrogen dynamics following incorporation and surface application of labelled crop residues in soil columns. Eur J Soil Sci. 2010;57(6):894-905.

36. Frey SD, Elliott ET, Paustian K. Bacterial and fungal abundance and biomass in conventional and no-tillage agroecosystems along two climatic gradients. Soil Biol Biochem. 1999;31(4):573-85.

37. Dong SS, Dou S. Effect of different ways of corn stover application to soil on composition and structural characteristics of organic carbon in black soil. J Agro-Environ Sci. 2017;36(002):322-8.

38. Jiang Y, Liao P, van Gestel N, Sun YN, Zeng YJ, Huang S, et al. Lime application lowers the global warming potential of a double rice cropping system. Geoderma. 2018;325:1-8.
39. Liao $B$, Wu X, Yu Y, Luo S, Lu G. Effects of mild alternate wetting and drying irrigation and mid-season drainage on $\mathrm{CH}_{4}$ and $\mathrm{N}_{2} \mathrm{O}$ emissions in rice cultivation. Sci Total Environ. 2019;698:134-212.

40. Feng $Y, X u Y, Y u Y, X i e Z$, Lin X. Mechanisms of biochar decreasing methane emission from Chinese paddy soils. Soil Biol Biochem. 2012;46(1):80-8.

41. Thakur AK, Mohanty RK, Patil DU, Dhiraj U, Ashwani K. Impact of water management on yield and water productivity with system of rice intensification (SRI) and conventional transplanting system in rice. Paddy Water Environ. 2013;12(4):413-24.

42. Wang $M$, Zhang $Z$, Chunbo L, Lin $Y$. $\mathrm{CH}_{4}$ and $\mathrm{N}_{2} \mathrm{O}$ emissions from rice paddy field and their GWPs research in different irrigation modes in cold region. Res Soil Water Conserv. 2016;23(2):95-100.

43. Li DM, Cheng YH, Liu MQ, Qin JT, Jiao JG, Li HX, et al. Effects of Nonflooded with straw mulching management on methane emission and rice yield in paddy field. J Agro-Environ Sci. 2012;31(10):2053-9.

44. Thangarajan R, Bolan NS, Tian G, Naidu R, Kunhikrishnan A. Role of organic amendment application on greenhouse gas emission from soil. Sci Total Environ. 2013;465:72-96.

45. Yao Z, Zheng X, Rui W, Xie B, Butterbach-Bahl K, Zhu J. Nitrous oxide and methane fluxes from a rice-wheat crop rotation under wheat residue incorporation and no-tillage practices. Atmos Environ. 2013;79(11):641-9.

46. Khosa MK, Sidhu BS, Benbi DK. Effect of organic materials and rice cultivars on methane emission from rice field. J Environ Biol. 2010;31(3):281.

47. Bayer C, Costa FD, Pedroso GM, Zschornackc T, Camargoa ES, de Lima MA, et al. Yield-scaled greenhouse gas emissions from flood irrigated rice under long-term conventional tillage and no-till systems in a Humid Subtropical climate. Field Crop Res. 2014;162:60-9.

48. Zhang ZS, Guo LJ, Liu TQ, Li CF, Cao CG. Effects of tillage practices and straw returning methods on greenhouse gas emissions and net ecosystem economic budget in rice-wheat cropping systems in central China. Atmos Environ. 2015;122:636-44.

49. Zou J, Yao H, Lu Y, Zheng $X$, Wang Y. Direct emission factor for $\mathrm{N}_{2} \mathrm{O}$ from rice-winter wheat rotation systems in southeast China. Atmos Environ. 2005;39(26):4755-65.

50. Yang SY, Yan P, Ma YH, Han HB, Wang DL, Fang HY. Effects on emissions of soil greenhouse gas by fertilizing to winter wheat. Ecol Environ Sci. 2010;19(7):1642-5

51. Le Mer J, Roger P. Production, oxidation, emission and consumption of methane by soils: a review. Eur J Soil Biol. 2001;37(1):25-50.

52. Kool DM, Dolfing J, Wrage N, Groenigen JWV. Nitrifier denitrification as a distinct and significant source of nitrous oxide from soil. Soil Biol Biochem. 2011;43(1):174-8.

53. Wu D, Zhao Z, Han X, Meng F, Wu W, Zhou M, et al. Potential dual effect of nitrification inhibitor 3,4-dimethylpyrazole phosphate on nitrifier denitrification in the mitigation of peak $\mathrm{N}_{2} \mathrm{O}$ emission events in North China Plain cropping systems. Soil Biol Biochem. 2018;121:147-53.

54. Unger S, Máguas C, Pereira JOS, David TS, Werner C. The influence of precipitation pulses on soil respiration-assessing the "Birch effect" by stable carbon isotopes. Soil Biol Biochem. 2010;42(10):1800-10.

55. Liu C, Wang K, Meng S, Zheng X, Zhou Z, Han S, et al. Effects of irrigation, fertilization and crop straw management on nitrous oxide and nitric oxide emissions from a wheat-maize rotation field in northern China. Agric Ecosyst Environ. 2011;140(1-2):226-33.

56. Borken W, Matzner E. Reappraisal of drying and wetting effects on $C$ and $\mathrm{N}$ mineralization and fluxes in soils. Glob Change Biol. 2009;15(4):808-24.

57. Smith P, Lanigan G, Kutsch WL, Buchmann N, Eugster W, Aubinet M, et al. Measurements necessary for assessing the net ecosystem carbon budget of croplands. Agric Ecosyst Environ. 2010;139(3):302-15.

58. Wang SC, Zhao YW, Wang JZ, Zhu P, Cui X, Han XZ, et al. The efficiency of long-term straw return to sequester organic carbon in Northeast China's cropland. J Integr Agric. 2018;17(2):436-48.

59. Yang X, Meng J, Lan Y, Chen WF, Yang TX, Yuan J, et al. Effects of maize stover and its biochar on soil $\mathrm{CO}_{2}$ emissions and labile organic carbon fractions in Northeast China. Agric Ecosyst Environ. 2017;240:24-31.

60. Zhao Y, Xue Z, Guo H, Mu X, Li C. Effects of tillage and crop residue management on soil respiration and its mechanism. Trans Chin Soc Agric Eng. 2014;30(19):155-65.

61. He J, Li HM, Li F, Hu X, Kong WC. Influence of straw application on agricultural greenhouse gas emissions in China. Chin Agric Sci Bull. 2011;27(20):246-50. 
62. Heintze G, Eickenscheidt T, Schmidhalter U, Drösler M. Influence of soil organic carbon on greenhouse gas emission potential after application of biogas residues or cattle slurry: results from a pot experiment. Pedosphere. 2017;27(5):807-21.

63. Kuzyakov Y. Priming effects: interactions between living and dead organic matter. Soil Biol Biochem. 2010;42(9):1363-71.

64. Cayuela ML, Velthof GL, Mondini C, Sinicco T, Groenigen JWV. Nitrous oxide and carbon dioxide emissions during initial decomposition of animal by-products applied as fertilisers to soils. Geoderma. 2010;157(3-4):235-42.
65. Li S, Li YB, Li XS, Tian XH, Zhao AQ, Wang SJ, et al. Effect of straw management on carbon sequestration and grain production in a maize-wheat cropping system in Anthrosol of the Guanzhong Plain. Soil Tillage Res. 2016;157:43-51.

\section{Publisher's Note}

Springer Nature remains neutral with regard to jurisdictional claims in published maps and institutional affiliations.
Ready to submit your research? Choose BMC and benefit from:

- fast, convenient online submission

- thorough peer review by experienced researchers in your field

- rapid publication on acceptance

- support for research data, including large and complex data types

- gold Open Access which fosters wider collaboration and increased citations

- maximum visibility for your research: over $100 \mathrm{M}$ website views per year

At BMC, research is always in progress.

Learn more biomedcentral.com/submissions 